\title{
Genetic characterization of the Moxotó goat breed using RAPD markers
}

\author{
Rejane Rodrigues de Oliveira(1), Andréa Alves do Egito(2), Maria Norma Ribeiro(1), Samuel Rezende Paiva(2), \\ Maria do Socorro Maués Albuquerque ${ }^{(2)}$, Silvia Ribeiro Castro ${ }^{(2)}$, Arthur da Silva Mariante ${ }^{(2)}$ e Manuel Adrião $0^{(1)}$
}

(1)Universidade Federal Rural de Pernambuco, R. Dom Manoel de Medeiros, s/no, Dois Irmãos, CEP 52171-900 Recife, PE, Brazil. E-mail: rejaneoliveirabr@yahoo.com.br, mn.ribeiro@uol.com.br, manoeladriao@yahoo.com.br (2)Embrapa Recursos Genéticos e Biotecnologia, Caixa Postal 02372, CEP 70770-900 Brasília, DF, Brazil. E-mail: egito@cenargen.embrapa.br, samuel@cenargen.embrapa.br, maues@cenargen.embrapa.br, silvia@cenargen.embrapa.br, mariante@cenargen.embrapa.br

\begin{abstract}
The objective of this study was to verify the genetic diversity between and within seven populations of Moxotó goat $(\mathrm{n}=264)$ from the States of Pernambuco, Paraíba and Rio Grande do Norte, using RAPD (Random Amplified Polymorphic DNA). Moxotó, as well as other naturalized breeds, suffers genetic losses due to the indiscriminate miscegenation with breeds raised in the Northeast Region of Brazil. The genetic characterization of these genetic resources is essential to conservation and breeding programs. DNA was extracted from lymphocytes using a non-organic protocol. The 16 primers used were selected from 120 decamer oligonucleotide primers and generated 56 polymorphic bands. The analysis of molecular variance (AMOVA) showed that the greater part of total genetic variability $(71.55 \%)$ was due to differences between individuals within populations, while $21.21 \%$ was among populations. The analysis of variance among the pairs of populations demonstrated that the populations located in Floresta, PE x Angicos, RN presented a smaller value of intrapopulational differentiation (8.9\%), indicating low genetic variability among them. Nei's genetic distances varied between 0.0546 and 0.1868 in the populations. The dendrogram generated showed that the Canindé breed, used as outgroup, clustered with the populations of Moxotó, indicating a possible common origin of the naturalized goat breeds.
\end{abstract}

Index terms: Capra hircus, native breeds, population structure, conservation genetics.

\section{Caracterização genética da raça caprina Moxotó por marcadores RAPD}

Resumo - O objetivo deste estudo foi verificar a diversidade genética entre e dentro de sete populações de cabras Moxotó ( $\mathrm{n}=264$ ) dos Estados de Pernambuco, Paraíba e Rio Grande do Norte, usando a técnica de RAPD (Poliformismo de DNA Amplificados ao Acaso). A raça Moxotó, assim como outras naturalizadas, sofre grande erosão genética devido à miscigenação indiscriminada com outras raças existentes na Região Nordeste. A caracterização genética desta raça é essencial para programas de conservação e melhoramento. Os marcadores moleculares são uma ferramenta útil na estimativa da diversidade genética de diferentes populações. O DNA foi extraído a partir de linfócitos utilizando-se um protocolo não orgânico. Os 16 primers utilizados foram selecionados a partir de 120 oligonucleotídeos e geraram 56 bandas polimórficas. A análise de variância molecular (AMOVA) demonstrou que a maior parte da variabilidade genética total $(71,55 \%)$ ocorreu em virtude das diferenças entre indivíduos dentro das populações, enquanto $21,21 \%$ ocorriam entre as populações. A análise da variância entre os pares de populações demonstra que as populações de Floresta, PE x Angicos, RN apresentam o menor valor de diferenciação interpopulacional (8,9\%), indicando menor variabilidade entre elas. A distância genética de Nei variou entre 0,0546 e 0,1868 nas populações. O dendrograma gerado demonstra que a raça Canindé, utilizada como outgroup, agrupa-se com as populações de Moxotó, indicando a possível origem comum das raças naturalizadas.

Termos para indexação: Capra hircus, raças nativas, estrutura de populações, conservação genética.

\section{Introduction}

Most naturalized goat breeds descend from animal introduced in Brazil by European settlers. Caprine populations are concentrated in the Northeast of the country where they are extremely adapted. The long natural selection process that they underwent generated small and sturdy animals with high fertility rates and well 
adapted to adverse conditions present in the Brazilian semi-arid. Moxotó breed, as well as the other naturalized Brazilian goat breeds, suffers genetic losses due to the indiscriminate miscegenation with other breeds raised in the Region. This miscegenation was caused by the deficiency of reproductive control and the disorientated introduction of exotic breeds. Nowadays, animals without breed definition represent $95 \%$ of caprine population in the Northeast (Oliveira, 2003).

Moxotó breeds are white or cream and present a black stripe that extends from the superior edge of the neck to the base of the tail, black aureoles around the eyes and two black stripes that go down to the tip of the snout. The underbelly, member extremities, muzzle, hooves and udder are black (Jardim, 1974). Probably, they descend from the Serpentina breed, which still exists in Portugal (Mariante \& Cavalcanti, 2000). Because it is breed hardy as well as prolific and well adapted to the Semi-arid Region, this breed represents important genetic resource that must be conserved.

The essential ingredient of the programs for rational conservation and improvement is the analysis of the genetic variability of the breed or population in study. These programs must be based on the combination of phenotypic and genetic data, and the analysis will assist in the development and rational monitoring of future programs of animal improvement, as well as in the preservation and conservation of animal germplasm. The results obtained based on the study of the differences and similarities between the populations as well as the estimation of the genetic variability within the breeds and populations will help in the choice of animals to be used as donors in ex situ conservation, assuring that the germplasm bank will contain the maximum genetic variability which exists in the populations, avoiding duplication of samples (animals with high genetic similarity). Since most of the in situ populations are small, low genetic variance must be assumed; therefore these estimates can be used in crossbreeding and genetic samples exchange between different nuclei. These studies may also be useful when establishing new nuclei (Egito et al., 1999).

Molecular markers have been shown to be an efficient tool in the quantification of genetic diversity of various populations (Saitbekova et al., 1999; Barker et al., 2001). RAPD (Random Amplified Polymorphic DNA) method, when compared to other techniques, is attractive, since it is relatively easy to run, fast and presents low cost. Various polymorphisms can be detected using small quantities of DNA without the use of radioactive material. Detected polymorphisms are inherited in a Mendelian pattern and may be generated in several species when the informative DNA sequence is unknown (Williams et al., 1990).

The objective of this study was to verify the genetic diversity between and within seven populations of the Moxotó goat breed located in three Brazilian Northeastern States, Pernambuco, Paraíba and Rio Grande do Norte.

\section{Material and Methods}

Seven populations of Moxotó goat breed from the following townships were studied: Patos (L1) and Santa Luzia do Cariri (L2), in Paraíba State; Serra Talhada (L3), Ibimirim (L4) and Floresta (L5), in Pernambuco State; and Pedro Avelino (L6) and Angicos (L7), in Rio Grande do Norte State (Table 1). Animals of other Brazilian native breed, Canindé, were included as outgroup.

The management used in $\mathrm{L} 1$ and $\mathrm{L} 2$ is semi-extensive - the animals are confined during the night (during the day the animals are free in areas of natural vegetation caatinga), with supplementary food and reproductive and health management. In L3 and L4, the management is similar to slight severity in the reproductive management. L5 presents an ultra-extensive management, in which the animals are confined twice a month; the breeds, sires and offspring are not separated and most of the animals

Table 1. Characterized populations of Moxotó goat.

\begin{tabular}{ll}
\hline Population & Localization \\
\hline L1 & Paraíba Federal University, Patos, Paraíba \\
L2 & Açudinho Farm, Santa Luzia do Cariri, Paraíba \\
L3 & Barra da Carnaúba Farm, Serra Talhada, Pernambuco \\
L4 & Livramento Farm, Ibimirim, Pernambuco \\
L5 & Camponesa Farm, Floresta, Pernambuco \\
L6 & Belo Monte Farm, Pedro Avelino, Rio Grande do Norte \\
L7 & São Miguel Farm, Angicos, Rio Grande do Norte \\
Canindé breed (Ca) DNA bank of Embrapa Cenargen
\end{tabular}


are derived from country fairs without knowing its origin and genetic composition. L6 and L7 are in the same region (Cabugi). In L6, the management is semiextensive and some animals have genealogic registration. In L7, the management is similar to L5 (Oliveira, 2003).

The genetic analysis was carried out in the Animal Genetics Laboratory (AGL) at Embrapa Genetic Resources and Biotecnoloy - Cenargen. Genomic DNA extraction from blood cells of individuals was based on Miller et al. (1988), slightly modified. A total of 120 decamer oligonucleotide primers (Operon Technologies Inc., Alameda, Calif.: $\mathrm{A}, \mathrm{AB}, \mathrm{AE}, \mathrm{J}, \mathrm{N}$ and $\mathrm{S}$ ) were screened using unique samples of DNA from distinct populations. A total of 16 primers (AB05, AB01, AE20, AB02, N19, N13, A12, AB4, S01, S18, A11, AE16, AE12, AB09, AE18 and J10) were selected and used to amplify DNA from all individuals.

RAPD-PCR reactions were carried out in a final volume of $13 \mu \mathrm{L}$, with $20 \mathrm{mM}$ Tris- $\mathrm{HCl}$ (pH 8.4), $50 \mathrm{mM} \mathrm{KCl}, 3.5 \mathrm{mM} \mathrm{MgCl}_{2}, 200 \mu \mathrm{M}$ of each dNTP, $8 \%$ of the $2.5 \mathrm{mg} / \mathrm{mL}$ BSA, $0.4 \mu \mathrm{M}$ of the arbitrary primer, $1.5 \mathrm{U}$ Taq DNA polymerase and $9 \mathrm{ng}$ of DNA. Reactions were performed in a MJ Research (PTC100) thermocycler under 40 cycles of 15 second duration at $95^{\circ} \mathrm{C}, 30$ seconds at $35^{\circ} \mathrm{C}$, one minute at $72^{\circ} \mathrm{C}$ and, at the end of the cycles, seven minutes at $72^{\circ} \mathrm{C}$, for complete extension of the amplified products.

Fragment data were entered in a computer file as a binary matrix (0/1). Data were analyzed using NTSYSpc, version 1.7 (Rohlf, 1992). Similarities between individuals were estimated using Jaccard coefficients of similarity (Sneath \& Sokal, 1973) and the resulting pairwise similarities were expressed as distance matrices.

Nei's genetic distances (Nei, 1972, 1978) between populations were calculated using the PopGene program (Population Genetic Analysis) version 1.31 (Yeh et al., 1999). All cluster analyses were conducted using UPGMA (unweighted pair group method with arithmetic mean) and the resulting clusters were expressed as dendrograms. The PopGene program also generated gene diversity indices for each population, as a function of the means of their allelic frequencies, based on Nei (1973). Confidence values of each node of dendrogram were estimated from 10,000 random resamplings of the data (bootstrap) using TFPGA (Tools for Population Genetics Analyses, version 1.3) (Miller, 1997).

Analysis of molecular variance (AMOVA) (Excoffier et al., 1992) was used to separate the variance between and within populations of Moxotó breed and between the two breeds analyzed (Moxotó and Canindé) using the Arlequin program (Schneider et al., 2000).

\section{Results and Discussion}

A total of 56 RAPD markers were generated by the 16 primers used to amplify DNA from all individuals AB05 (7 bands), AB01 (4 bands), AE20 (2 bands), AB02 (4 bands), N19 (5 bands), N13 (4 bands), A12 (4 bands), AB4 (2 bands), S01 (4 bands), S18 (4 bands), A11 (3 bands), AE16 (01 band), AE12 (3 bands), AB09 (3 bands), AE18 (01 band) and $\mathrm{J} 10$ (5 bands).

The greater percentage of variation $(71.55 \%)$ was observed inside the population of Moxotó (Table 2). The variation due to differences between the two breeds was of $7.24 \%$. This variation is smaller than that observed by Serrano (2001), studying genetic diversity in bovine breeds and by Saitbekova et al. (1999), studying Swiss goats, who found differences of $16.27 \%$ and $17 \%$, respectively.

The values among $(21.21 \%)$ and within $(71.55 \%)$ the populations were a little below those observed by Ajmone-Marsan et al. (2001) and Crepaldi et al. (2001), who found $75 \%$ and $91.2 \%$, respectively, for the variation within the populations in studies of genetic diversity with use of molecular markers in Italian native goats.

The results obtained by AMOVA analysis when comparing population pairs were significant at $5 \%$ level,

Table 2. Molecular variance analysis (AMOVA) of seven populations of Moxotó breed and the Canindé outgroup, obtained with 56 RAPD markers.

\begin{tabular}{lrrcc}
\hline Source of variation & df & $\begin{array}{r}\text { Sum of } \\
\text { squares }\end{array}$ & $\begin{array}{c}\text { Variance } \\
\text { components }\end{array}$ & $\begin{array}{c}\text { Percentage of } \\
\text { variation }\end{array}$ \\
\hline Between breeds & 1 & 67.304 & 67.30 & $7.24^{* *}$ \\
Among populations ${ }^{(1)}$ & 6 & 472.685 & 78.78 & $21.21^{* *}$ \\
Within populations & 274 & 1806.923 & 6.59 & 71.55 \\
\hline
\end{tabular}

${ }^{(1)}$ Only populations of Moxotó breed. ${ }^{* *}$ Significant at $1 \%$ probability. 
indicating that they can be considered as distinct genetic entities (Table 3).

The lowest genetic variability was observed between L7 $x$ L5 populations (8.9\%) and the greatest variability was L1 x Canindé (39.33\%). When only Moxotó breed was considered, the greatest variability was observed between L1 x L5 (36.85\%). The pairs varied from $8.90 \%$ to $36.85 \%$, which is in compliance with that obtained by Oufi et al. (2002), that reported values between $4.99 \%$ and $43.69 \%$ in their work on genetic studies with STRs markers in Morocco's goat breed.

The analysis of gene diversity is an alternative method to measure the variation present in a population and is one of the most appropriate measures to determine the variability of closest populations that can have some degree of consanguinity (Weir, 1996). Gene diversity index (Nei, 1973) was calculated for all breeds, considering them as unique populations (Table 4). This analysis was based on the mean allelic frequency of the 56 RAPD markers.

Table 3. Percentage of genetic variation due to the differences between populations estimated by Molecular Variance Analysis, for all pairs confronted ${ }^{(1)}$.

\begin{tabular}{ccccccccc}
\hline Population & L1 & L2 & L3 & L4 & L5 & L6 & L7 & Ca \\
\hline L1 & - & & & & & & & \\
L2 & $14.55^{*}$ & - & & & & & & \\
L3 & $34.06^{*}$ & $24.98^{*}$ & - & & & & & \\
L4 & $36.02^{*}$ & $26.14^{*}$ & $19.45^{*}$ & - & & & & \\
L5 & $36.85^{*}$ & $23.40^{*}$ & $27.45^{*}$ & $14.61^{*}$ & - & & & \\
L6 & $29.79^{*}$ & $15.31^{*}$ & $20.11^{*}$ & $23.40^{*}$ & $20.34^{*}$ & - & & \\
L7 & $32.14^{*}$ & $17.95^{*}$ & $18.26^{*}$ & $19.93^{*}$ & $8.90^{*}$ & $10.71^{*}$ & - & \\
Ca & $39.33^{*}$ & $25.62^{*}$ & $27.50^{*}$ & $26.59^{*}$ & $24.32^{*}$ & $26.42^{*}$ & $23.43^{*}$ & - \\
\hline
\end{tabular}

${ }^{(1)}$ Populations are identified on Table $1 .{ }^{*}$ Significant at $1 \%$ probability.

Table 4. Nei's gene diversity index calculated for all populations, considering them as unique populations, based on the mean allelic frequency of the 56 RAPD markers.

\begin{tabular}{ccc}
\hline Population $^{(1)}$ & $\begin{array}{c}\text { Number of } \\
\text { individuals analyzed }\end{array}$ & $\begin{array}{c}\text { Gene diversity } \\
\text { index }\end{array}$ \\
\hline L1 & 48 & $0.3016( \pm 0.1624)$ \\
L2 & 48 & $0.3318( \pm 0.1818)$ \\
L3 & 37 & $0.2447( \pm 0.1956)$ \\
L4 & 18 & $0.2628( \pm 0.1977)$ \\
L5 & 17 & $0.2202( \pm 0.2053)$ \\
L6 & 48 & $0.2662( \pm 0.1843)$ \\
L7 & 48 & $0.2520( \pm 0.1983)$ \\
Ca & 18 & $0.2328( \pm 0.2035)$ \\
\hline (1) Populations are identified on Table 1 &
\end{tabular}

(1)Populations are identified on Table 1.
The lower indices were observed in L5 (0.2202) and $\mathrm{Ca}(0.2328)$ (Table 4), reflecting the endogamy present in these populations due to the reduced number of individuals (Oliveira, 2003). The populations that presented the highest indices of gene diversity were L2 (0.3318) and L1 (0.3016), indicating that both can supply individuals for breeding. This greater genetic variability reflects the semi-extensive management and the reproductive control used in these populations, not allowing the introduction of genes proceeding from other breeds (Oliveira, 2003).

The gene diversity index varied from 0.2202 to 0.3318 . Serrano (2001) observed indices that varied from 0.1342 to 0.2524 in bovine breeds populations and Spritze (2001), from 0.12036 to 0.24916 in different populations of the Crioulo Lageano bovine breed. In the caprine specie, Ajmone-Marsan et al. (2001) obtained values from 0.21 to 0.24, using AFLP markers and Saitbekova et al. (1999), with microsatellites, obtained values from 0.17 to 0.58 . These authors suggested that the low values are due to the great amount of monomorphic locus in the studied populations of Swiss goat breeds.

The estimates of genetic distances between the populations were calculated to help in the study of genetic relationships and genetic divergence between pairs of populations for standard genetic distances (Dp) (Nei, 1972) and those corrected for small populations (Dc) (Nei, 1978) (Table 5).

Although Dp was superior to Dc, they are highly correlated and the dendrograms generated for both were similar. For this reason, only the results derived from the

Table 5. Nei's genetic distances from RAPD data, using the PopGene program. The standard genetic distances are below the diagonal, and corrected distances, above the diagonal ${ }^{(1)}$.

\begin{tabular}{ccccccccc}
\hline Population $^{(1)}$ & L1 & L2 & L3 & L4 & L5 & L6 & L7 & Ca \\
\hline L1 & - & 0.0823 & 0.1511 & 0.1868 & 0.1822 & 0.1512 & 0.1427 & 0.2179 \\
L2 & 0.0872 & - & 0.1284 & 0.1596 & 0.1190 & 0.0744 & 0.0836 & 0.1260 \\
L3 & 0.1557 & 0.1333 & - & 0.0931 & 0.1236 & 0.1117 & 0.0793 & 0.1307 \\
L4 & 0.1942 & 0.1674 & 0.1005 & - & 0.0738 & 0.1396 & 0.1216 & 0.1433 \\
L5 & 0.1888 & 0.1259 & 0.1301 & 0.0832 & - & 0.1085 & 0.0548 & 0.1107 \\
L6 & 0.1554 & 0.0789 & 0.1158 & 0.1467 & 0.1148 & - & 0.0546 & 0.1433 \\
L7 & 0.1468 & 0.0880 & 0.0834 & 0.1285 & 0.0609 & 0.0583 & - & 0.1112 \\
Ca & 0.2245 & 0.1329 & 0.1373 & 0.1528 & 0.1193 & 0.1496 & 0.1173 & - \\
\hline (1) Populations are identified on Table 1. & & & & &
\end{tabular}


distances corrected for small populations were presented (Nei, 1978). The highest value was obtained between the populations $\mathrm{L} 1 \times \mathrm{Ca}(0.2179)$ and agrees with the percentages of variability obtained using AMOVA. The less divergent population in relation to the Canindé breed was the L7 (0.1112), also according to data obtained with AMOVA. This suggests that an L1 population is the most distant population from the Canindé breed. These results reflect the reproductive control and a breeding scheme used in L1, a "controlled herd", avoiding the risk of miscegenation with other populations. The extensive management used in $\mathrm{L} 7$ population, on the other hand, caused miscegenation not desired and, consequently, loss of proper characteristics of the Moxotó breed (Oliveira, 2003).

Inside Moxotó populations, the closest distances were observed between L5 x L7 (0.0548) and between L6 x L7 (0.0546). These results reflect the management of these populations. The L5 population is a herd formed by individuals from several places (Oliveira, 2003), which can explain its grouping with other populations, even geographically distant. They are animals that can have a high degree of miscegenation. The L6 and L 7 populations are located in the same region (Table 1), which might have facilitated the exchange of reproducers, justifying the genetic proximity between both. The greatest genetic distances were observed in the L1 x L4 (0.1868) and L1 x L5 (0.1822) population pairs. These values, added to the low diversity indices observed in L4 and L5 (Table 4), suggest that this distance could be caused by sample effect or differences in gene pool of the founders of the L1 herd.

The dendrogram generated by this analysis is in Figure 1. Two major clusters were formed - one by the L1 population and the biggest one formed by other populations and the Canindé outgroup. This could be indicative of the controlled reproduction management in L1 population (Oliveira, 2003), demonstrating its purity when compared with the others.

The grouping of Canindé breed with the populations of Moxotó goat (Figure 1) reflects a possible common origin of the Brazilian naturalized goat breeds (Domingues, 1942). Both breeds possess similar conformation, and the coat color is the determinative factor for the differentiation between them. Another point that must be taken into accounts is the number of DNA markers (56) used in this study. Serrano (2001) used 122 bands and Spritze (2001) has gotten 77 bands, both working with RAPD for study of genetic diversity of Brazilian naturalized bovine breeds.

The bootstrap for 10,000 permutations varied from $10.3 \%$ to $43.8 \%$ (Figure 1). The values obtained were not able to discriminate the real relationships between the studied populations (the minimum value would be $80 \%$ ). However, independently of the method used to generate molecular markers (RAPD, microsatellites or AFLP), other authors obtained similar values to these (Saitbekova et al., 1999; Barker et al., 2001; AjmoneMarsan et al., 2001).

An individual dendrogram was generated, using clustering method of UPGMA, based on the Jaccard's similarity coefficients matrix (Figure 2). Individuals of Canindé breed grouped together, however, as observed before, clustered with individuals of the populations of Moxotó breed, a grouping between the populations L1 and L2 that clustered separated from each other. Migration of individuals between the populations can be an indication of the flow of reproducers between the visited properties, since this is a very common practice in animal breeding in the Brazilian Northeast Region (Oliveira, 2003).

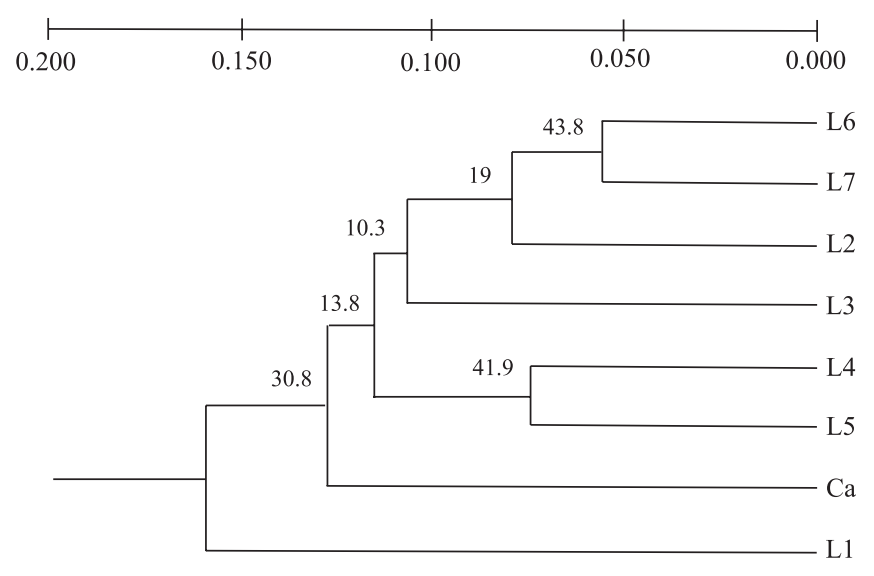

Figure 1. Dendrogram generated by the UPGMA method for Nei (1978) genetic distance using TFPGA program, the confidence value of each node was estimated from 10,000 permutations. 


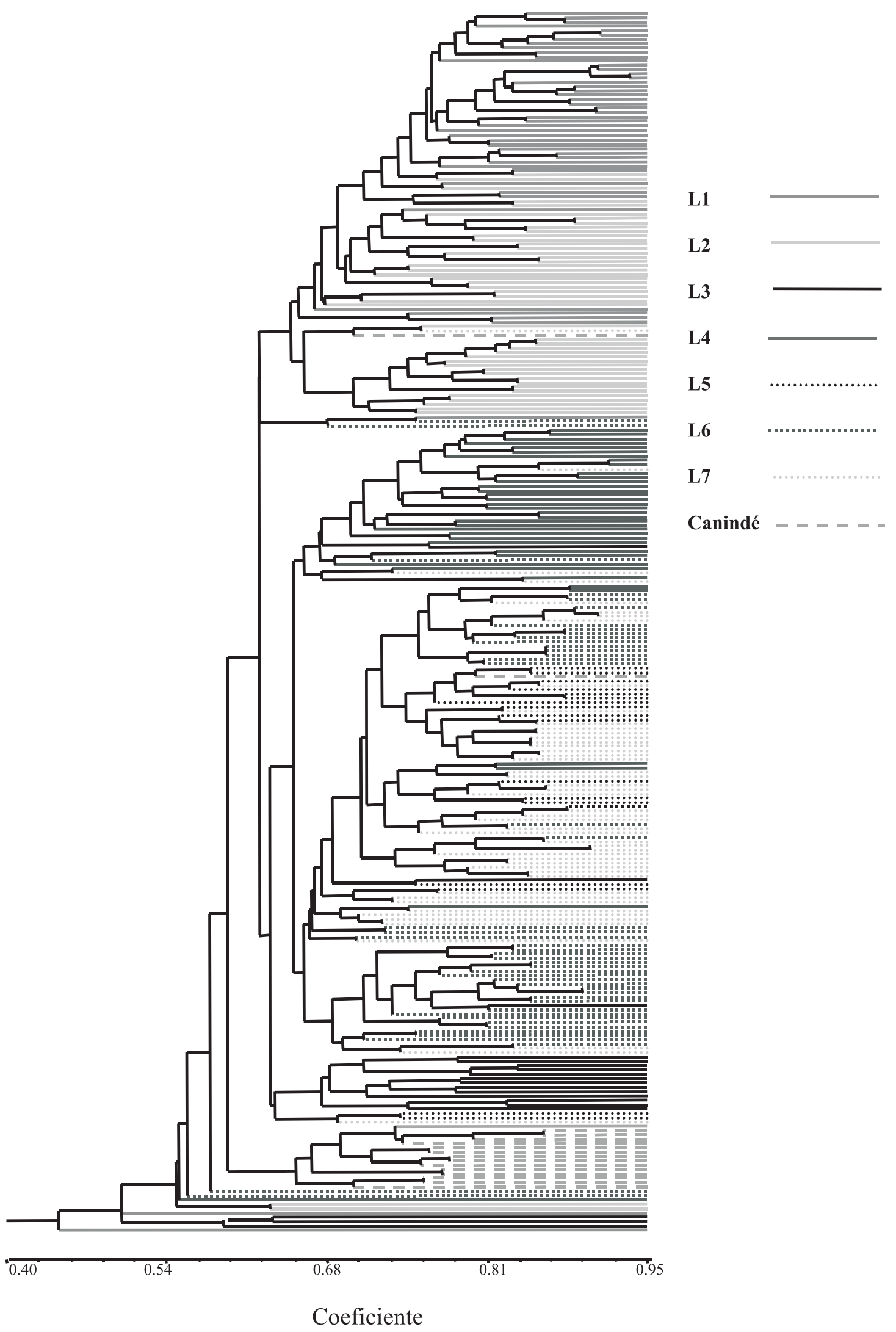

Figure 2. Individual dendrogram constructed from Jaccard similarity coefficient using NTSYS-pc program. 


\section{Conclusions}

1. The RAPD technique is an efficient method for studies of genetic similarity between Moxotó goat populations.

2. The studied populations can be considered as distinct genetic entities, proving the importance of its conservation.

3. The population that presents more definite genetic standard, based on RAPD markers, is the L1, followed for the L2, demonstrating the importance of a reproductive handling and control in breeding and conservation herds.

4. The Canindé breed, used as an outgroup, is relatively close to the Moxotó breed, suggesting a common origin or a miscegenation of both breeds.

\section{Acknowledgements}

To the private breeders, for having yielded the biological material used in this work; to Embrapa and Universidade Federal Rural de Pernambuco for grants supported.

\section{References}

AJMONE-MARSAN, P.; NEGRINI, R.; CREPALDI, P.; MILANESI, E.; GORNI, C.; VALENTINI, A.; CICOGNA, M. Assessing genetic diversity in Italian goat populations using AFLP markers. Animal Genetics, v.32, p.281-288, 2001.

BARKER, J.S.F.; TAN, S.G.; MOORE, S.S.; MUKHERJEE, T.K.; MATHESON, J.L.; SELVARAJ, O.S. Genetic variation within and relationships among populations of Asian goats (Capra hircus). Journal of Animal Breeding and Genetics, v.118, p.213-233, 2001.

CREPALDI, P.; NEGRINI, R.; MILANESI, E.; GORNI, C.; CICOGNA, M.; AJMONE-MARSAN, P. Diversity in five goat populations of the Lombardy Alps: Comparison of estimates obtained from morphometric traits and molecular markers. Journal of Animal Breeding Genetics, v.118, p.173-180, 2001.

DOMINGUES, O. À margem da Zootecnia - estudos e ensaios. 1.ed. Rio de Janeiro: ALBA, 1942. 384p.

EGITO, A.A.; ALBUQUERQUE, M.S.; MARIANTE, A.S. Situação atual da caracterização genética animal na Embrapa Recursos Genéticos e Biotecnologia. In: SIMPÓSIO DE RECURSOS GENÉTICOS PARA A AMÉRICA LATINA E CARIBE SIRGEALC, 2., 1999, Brasília. Anais. Brasília: Embrapa-Cenargen., 1999. 5p. Mesa redonda/mes010.pdf. CD-ROM.

EXCOFFIER, L.; SMOUSE, P.E.; QUATTRO, J.M. Analysis of molecular variance inferred from metric distances among DNA haplotypes: application to human mitochondrial DNA restriction data. Genetics, v.131, p.479-491, 1992.
JARDIM, W.R. Criação de Caprinos. São Paulo: Nobel, 1974. 240p. MARIANTE, A. da S.; CAVAlCANTE, N. Animais do descobrimento: raças domésticas da história do Brasil. Brasília: Embrapa-Cenargen, 2000. 232p.

MILLER, M.P. Tools for population genetics analyses (TFPGA) ver. 1.3: a Windows program for the analysis of allozyme and molecular population genetic data. Flagstaff: Northen Arizona University, 1997. 33p.

MILLER, S.A.; DYKES, D.D.; POLESKY, H.F. A simple salting out procedure for extracting DNA from human nucleated cells. Nucleic Acids Research, v.16, p.1215, 1988.

NEI, M. Analysis of gene diversity in subdivided populations. Proceedings of the National Academy of Sciences of United States of America, v.70, p.3321-3323, 1973.

NEI, M. Estimation of average heterozygosity and genetic distance from a small number of individuals. Genetics, v.89, p.583-590, 1978.

NEI, M. Genetic distance between populations. American Naturalist, v.106, p.238-292, 1972.

OLIVEIRA, R.R. Caracterização genética de populações de caprinos da raça Moxotó usando marcadores moleculares. 2003, 58p. Dissertação (Mestrado) - Universidade Federal da Paraíba, Areia.

OUFI, A.T.; BABILLIOT, J.M.; LEROUX, C.; MARTIN, P. Genetic diversity of the two main Moroccan goats breeds: phylogenetic relationships with four breeds reared in France. Small Ruminant Research, v.45, p.225-233, 2002.

ROHLF, F.J. NTSYS-pc ver 1.70: Numerical taxonomy and multivariate analysis system. Setauket: Exeter Software, 1992. 212p.

SAITBEKOVA, N.; GAILLARD, C.; OBEXER-RUFF, G.; DOLF, G. Genetic diversity in Swiss goats breeds based on microsatellite analysis. Animal Genetics, v.30, p.36-41, 1999.

SCHNEIDER, S.; ROESSLI, D.; EXCOFFIER, L. Arlequin ver. 2000: a software for population genetics data analysis. Geneva: University of Geneva, 2000. 111p.

SERRANO, G.M.S. Uso de marcadores moleculares RAPD na caracterização genética molecular das raças bovinas nativas Brasileiras. 2001, 87p. Dissertação (Mestrado) - Universidade de Brasília, Brasília.

SNEATH, P.H.A.; SOKAL, R.R. Numerical taxonomy: the principles and practice of numerical classification. San Francisco: W.H. Freeman, 1973. 573p.

SPRITZE, A.L. Uso de marcadores moleculares RAPD na caracterização genética da raça bovina Crioulo Lageano. 2001, 68p. Dissertação (Mestrado) - Universidade de Brasília, Brasília.

WEIR B.S. Genetic data analysis II: methods for discrete population genetic data. Sunderland: Sinauer Associates, 1996. 445p.

WILLIAMS, J.G.K.; KUBELIK, A.R.; LIVAK, K.J.; RAFALSKI, J.A.; TINGEY, S.V. DNA polymorphisms amplified by arbitrary primers are useful as genetics markers. Nucleic Acids Research, v.18, p.6531-6535, 1990.

YEH, F.C.; YANG, R.; BOYLE, T. POPGENE: Microsoft Window-based freeware for population genetic analysis: version 1.3: manual. Edmonton: University of Alberta, 1999. 29p. 